Unfortunately, because of the abundance of man-introduced rats, only just over 400 of the total of 2450 acres of island are available for birds. Dr Bellamy concludes with a plea for the elimination of the rats and an international agreement to make the whole of the Chagos Bank a nature reserve. He has certainly provided sufficient evidence to justify his proposals.

The book is generally well produced, with attractive layout and plenty of pictures, marred only by Dr Bellamy's rather ponderous humour, especially evident in picture captions; his message is clear enough without this jokiness. It is a pity, too, that he and the editors did not take the trouble to ensure that some of the more tortuous paragraphs were clarified. But it is a book with a worthy aim, and contains a great deal of interest to specialist and non-specialist alike.

S.R.J. WOODELL

\title{
Harpooned, by Bill Spence. Conway Maritime Press, £9.50.
}

Development in Britain's whaling industry before the end of the 18th century resembles nothing so much as the current plight of British Leyland. Early production was abysmally low, largely through incompetent management, and foreign competitors were thriving, especially the Dutch, who also hogged the best whaling grounds. The British Government helped by slapping heavy taxes on foreign whale product imports and offering bounties to the British, but when our chaps finally got their strategy right they were beaten up by the French navy, the two countries by then being at war. Now, of course, Japan and Russia lead the field and everyone else is trying to stop them.

All this, and what came before, between and after, has been remarkably well researched by Bill Spence. In a highly readable fashion he tells the story of commercial whaling from the 12 th century to the middle of the 20th; of successive depletion of whale populations; and of successive leaders in the industry - Spain, Holland, Great Britain, America, Norway and now Japan. I always like the extra little 'throw-away' snippets in books like this, that bring history to life. It was news to me, for example, that the three ships from which tea was thrown overboard in Boston, 1772, had been brimming with whale oil in their previous voyage, which could have put a new complexion on the Boston Tea Party.

If the title suggests a text about whales it is misleading; this is about the anatomy and incipient extinction of an industry.

JON BARZDO

\section{A Field Guide to the Land Snails of Britain and North-West Europe, by M.P. Kerney and R.A.D. Cameron. Collins, £5.50.}

In the heyday of malacology, over a century ago, a number of well-illustrated books were available for the enthusiastic amateur; today this is not so, and this volume fills the gap. All 279 species occurring in the area are described, and most are illustrated. Gordon Riley's illustrations are meticulous and - to a non-specialist such as myself adequate for identifying most species, with the help of the text. The colour plates are far less pleasing than the line drawings, the colours seeming a little bleached; in trying to give the slugs (and snails) a wet slimy appearance he (or the publisher) has lost the richness of colour of some - Arion ater the familiar $10-\mathrm{cm}$ black or orange slug is a pale ghost of its real self.

Collins has also departed from normal field guide style by including dissections. Admittedly some species are difficult to identify, but it seems a little outside the scope of a field guide, as does the micro-structure of the shell, which needs a binocular microscope to observe. Perhaps this is merely a criticism of the title, since the important thing is to identify the slugs and snails! The maps, covering 276 species, with the British species mapped in even greater detail, are particularly instructive and useful. In 